\title{
PENGAJIAN REMAJA DAN KONTRIBUSINYA DALAM PEMBENTUKAN AKHLAK GENERASI MUDA DI BULAK SETRO SURABAYA
}

\author{
Oleh: \\ Achmad Nawawi ${ }^{1}$ \\ Email: iwawan12@gmail.com
}

\begin{abstract}
Spiritual spirits is a non-formal education activities conducted in a place of worship in an Islamic society as a place to deepen and examine the knowledge of religion, whether morals, worship, or muamalah. While the material is taught in spiritually spirited teen Bulak Setro is more to morality material that aims to shape morals on the younger generation. While teenagers spiritual spirits efforts conducted by teenagers Bulak Setro in forming the morality of the young generation that is by providing education, pedagogy, habituation, and exemplary to the congregation (members) sprinkling the spiritual. This research uses qualitative approach, with observation research technique, documentation, and interview. As for data analysis in this study using qualitative analysis. The credible test uses triangulation or checking data from multiple sources in various ways and times. The study of adolescents has a huge contribution in the formation of morality of the younger generation in the future, the region prepares its generation with positive things so it becomes a habit for teenagers to attend a recitation, as an exercise to cultivate a sense of responsibility by becoming a tutor, without losing their adolescence, because people still give them the freedom to play and hang out like any other teenager.
\end{abstract}

Keywords : teenage spirits, contribution, formation of morals

\section{Pendahuluan}

Generasi muda (remaja) sebagai generasi penerus di masa yang akan datang. Maju dan berkembangnya suatu bangsa terletak di tangan mereka, dengan kata lain, jika generasi muda suatu bangsa baik, maka bangsa

${ }^{1}$ Dosen STAI Taruna Surabaya. 
tersebut akan maju dan berkembang, begitu juga sebaliknya, jika generasi muda suatu bangsa buruk, maka besar kemungkinan pula suatu bangsa akan mengalami kemunduran. Generasi muda merupakan generasi penentu yang akan melanjutkan estafet perjuangan bangsa, sehingga penanaman akhlak sebagai langkah awal dalam mempersiapkan kemajuan dan perkembangan bangsa di masa yang akan datang.

Masa remaja merupakan masa transisi dari anak-anak menuju dewasa, masa ini lebih dikenal dengan masa abu-abu, dimana dalam masa mereka telah dirundung rasa ego yang tinggi, sehingga membutuhkan arahan dan bimbingan. Mereka memiliki rasa keingintahuan yang begitu besar, sehingga jika tak tertanam hal positif dalam diri mereka dan lengah dalam mengawasi mereka, maka berbagai hal negatif ingin dicobanya.

Pada zaman sekarang banyak sekali remaja yang memiliki kecenderungan memprihatinkan, terutama dalam masalah tingkah laku, sikap, akhlak, dan moral. Banyak remaja yang terlibat dalam tindakan kriminalitas, mulai dari tawuran, penggunaan obat-obat terlarang, pergaulan bebas, kriminalitas, dan kenakalan lainnya. Seorang remaja tak cukup hanya diberikan siraman rohani berisi sejumlah doktrin agama saja yang kemudian ditelan mentah-mentah, namun doktrin agama ini harus ditelaah lebih dalam sehingga mereka benar-benar telah mengetahui pentingnya pengetahuan agama dan akhlak sebagai bekal pedoman hidup di masa yang akan datang.

Pengetahuan agama sama halnya dengan pendidikan agama Islam, dan akhlak merupakan substansi dari pendidikan agama Islam tersebut. Pendidikan agama dianggap sangat penting, karena dapat membentuk kepribadian yang lebih baik dengan terwujudnya sikap dan tingkah laku dalam sehari-hari. Menurut Zakiah Daradjad pendidikan agama hendaknya bisa mewarnai kehidupan anak sehingga dengannya benarbenar menjadi bagian dari sebuah kepribadian yang akan menjadi pengendali dalam kehidupan di kemudian hari. ${ }^{2}$

Islam adalah agama yang bersifat universal, dimana semua kehidupan mulai hal yang kecil sampai hal yang besar diatur dalam al-Qur'an, kitab

${ }^{2}$ Zakiah Daradjat. Ilmu Gama. Jakarta: Bulan Bintang, 1970, Cet. Ke-14, 7. 
yang diturunkan kepada Nabi Muhammad sebagai pedoman hidup agama Islam untuk mencapai tujuan hidup umat Islam. Dalam pandangan Islam, manusia terlahir dalam keadaan fitrah yang suci, Allah SWT menciptakan manusia disertai dengan naluri beragama, yaitu agama tauhid. Islam mewajibkan bagi para penganutnya untuk mendakwahkan dan mensyiarkan seluruh ajaran yang terkandung di dalamnya, seperti firman Allah dalam surat Ali Imron ayat 104:

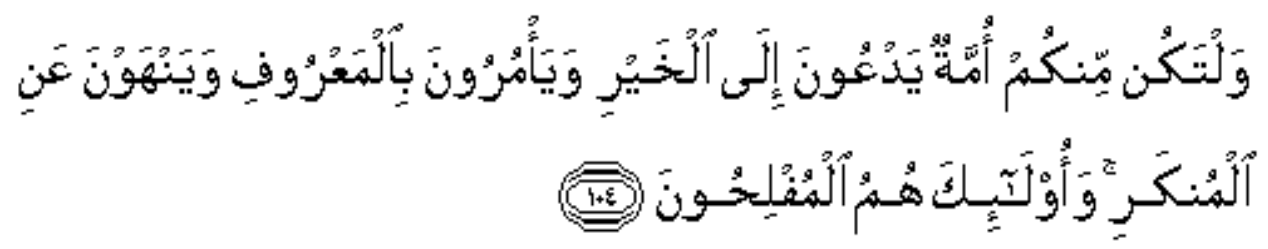

"Dan hendaklah ada di antara kamu segolongan umat yang menyeru kepada kebajikan, menyuruh kepada yang ma'ruf dan mencegah dari yang munkar, merekalah yang beruntung."

Dalam mensyiarkan Islam yang mengutamakan keimanan dan ketakwaan kepada Allah SWT, maka perlu juga ditanamkan akhlak yang mulia. Karena akhlak tak dapat terbentuk dengan cara yang cepat atau langsung. Jadi, tidak mudah membentuk suatu akhlak dalam diri seseorang, harus dengan upaya keras dengan melalui proses yang begitu lama dan usaha yang sungguh-sungguh. Dalam pembentukan akhlak generasi muda, harus dengan teladan dan contoh yang baik, dengan pembiasaan secara kontinyu baik melalui pendidikan formal, informal, dan non formal.

Pendidikan agama Islam memiliki beberapa sarana dan prasarana yang dapat kita lihat dalam bentuk dan wujudnya seperti perlengkapan belajar mengajar, tenaga pendidik yang berkompeten dalam bidangnya, tempat proses belajar mengajar yaitu: masjid, musholla, sekolah, madrasah ataupun lainnya. Sebagai sarana perkembangan pengetahuan umum

${ }^{3}$ Depag RI. Al Qur'an dan Terjemahannya. Jakarta: Proyek Pengadaan Kitab Suci Al-Qur'an. 1983/1984. 93. 
diselenggarakan secara formal di beberapa sekolah, sedangkan informal dalam keluarga, dan non formal diselenggarakan oleh masyarakat di beberapa tempat ibadah Islam seperti masjid dan musholla. Tempat ini digunakan sebagai sarana dakwah atau penyebaran agama Islam.

Keberhasilan seseorang dalam mensyiarkan dan mendakwahkan ajaran Islam tergantung pada manhaj (metode) yang digunakan dalam media dakwah. Media dakwah banyak sekali yang dapat diterapkan, seperti tabligh akbar, pidato atau ceramah agama yang khususnya berkaitan dengan sosio kultural masyarakat.

Salah satu pendidikan non formal yang sering terlihat adalah pengajian, dimana kegiatan ini biasa dilakukan sebagai bentuk perkumpulan majlis dan silaturrahim antarwarga dengan pengembangan pengetahuan agama. Prof. Kuntowijoyo mengatakan kegiatan ini biasanya berpusat di lingkungan masjid yang mana masjid sangat mungkin sekali melakukan pembinaan terhadap jamaah di wilayahnya.

Sebagai salah satu contoh kegiatan yang diselenggarakan di lingkungan Bulak Setro yaitu pengajian remaja sebagai forum dan wadah persatuan para pemuda-pemudi setempat, kegiatan keagamaan ini dilaksanakan sebagai kegiatan rutin para remaja setiap malam Jum'at, dan mendapat dukungan dari para tokoh masyarakat. Dalam kegiatan pengajian ini, para remaja diberikan beberapa pendidikan ilmu agama, diharapkan dengan adanya kegiatan tersebut para remaja mampu mengambil dan mengamalkan ajaran agama dengan sebaik-baiknya, serta mengaplikasikan ajaran tersebut dalam bentuk prilaku sehari-hari.

Muzakir mengatakan bahwa pengajian ialah istilah umum yang digunakan untuk menyebut berbagai kegiatan belajar mengajar agama. ${ }^{4}$ Sedangkan Sudjoko Prasodjo menyatakan bahwa pengajian merupakan suatu kegiatan yang bersifat pendidikan kepada umum. ${ }^{5}$

Sementara Hasbullah mengemukakan bahwa pengajian atau majlis ta'lim agama Islam merupakan lembaga pendidikan non formal Islam yang memiliki kurikulum sendiri secara berkala dan teratur yang diikuti oleh

${ }^{4}$ Pradjarta Dirdjosanjoto. Memelihara Umat (Kiai Pesantren-Kiai Langgar di Jawa), Yogyakarta: LKIS. 1999, 3.

${ }^{5}$ Bahri Ghazali. Pesantren Berwawasan Lingkungan. Jakarta: Prasasti, 2003, 40. 
jamaah dari seluruh golongan usia. Aktivitas ini tak membatasi umur dan golongan tertentu, tetapi mencakup semua orang yang berminat untuk menjalin silaturrahim dan mendalami ajaran Islam dengan kesadaran masing-masing individu dari mereka. ${ }^{6}$

Pengajian dapat juga dapat dikatakan sebagai syiar Islam yang lebih dikenal dengan sebutan dakwah Islamiyah. Dakwah Islamiyah sebagai usaha terwujudnya ajaran agama dalam semua segi kehidupan, sehingga pengajian menyeru kepada yang ma'ruf dan mencegah yang mungkar.

Hidayat Nurwahid mengemukakan bahwa dakwah ialah kegiatan mengajak, mendorong, dan memotivasi orang lain berdasarkan bashiroh untuk meneliti jalan Allah dan Istiqomah di jalan-Nya, serta berjuang bersama meninggikan agama Allah.7

Berdasarkan pengertian di atas, dapat disimpulkan bahwa pengajian adalah sebuah kelompok atau jamaah yang memiliki keinginan untuk menambah pengetahuan agama, melalui pendidikan non formal dengan berbagai kegiatan atau aktifitas yang diselenggarakan oleh masyarakat setempat sebagai bentuk pembangunan nilai-nilai agama.

Pengajian pada hakekatmya adalah mengajak manusia pada kebaikan dan petunjuk Allah SWT, menyeru kepada kebiasaan yang baik dan melarang dari kebiasaan buruk agar mendapatkan kebahagiaan dunia dan akhirat. ${ }^{8}$

Di era seperti saat ini, pembinaan akhlak sangat diperlukan guna untuk menanamkan akhlak atau budi pekerti yang baik dalam diri seorang remaja sehingga dapat membentuk akhlak yang terpuji. Banyak para cendekiawan bahwa kerusakan dan kejahatan yang terjadi sekarang ini akibat dari manusia itu sendiri yang tak lagi memegang dan mengamalkan akhlak terpuji. Salah satu hal utama untuk membina akhlak generasi muda adalah melalui pengajian dan kegiatan keagamaan lainnya.

Ahmad Amin menegmukakan ada beberapa hal yang harus diperhatikan agar masa muda terlindungi dan terjaga dari kerusakan

${ }^{6}$ Hasbullah. Kapita Selekta Pendidikan Islam di Indonesia. Jakarta: Raja Grfindo Persada. 1999, 95-98.

${ }^{7}$ Hidayat Nurwahid. Pengantar Sejarah Dakwah. Jakarta: Kencana. 2012, 2.

${ }^{8}$ Munzier Suparta. Metode Dakwah. Jakarta: Kencana. 2009, 28. 
akhlak :9 (1) berfikir lebih luas, (2) berteman dengan orang-orang yang baik, dan (3) membaca dan menelisik perjalanan pahlawan yang berfikiran luas.

\section{Metode Penelitian}

Penelitian ini terfokus untuk memperoleh gambaran tentang pengajian remaja dan kontribusinya dalam pembentukan akhlak generasi muda di Bulak Setro Surabaya. Adapun jenis pendekatan yang digunakan adalah pendekatan kualitatif, karena data yang diambil adalah kualitatif. Rancangan dalam penelitian ini ialah studi kasus observasi, yang mana menurut Bogdan dan Bigien (1982) merupakan penelitian secara rinci terhadap satu latar, satu subjek, dan satu tempat penyimpanan dokumen atau satu peristiwa tertentu.

Penelitian ini lebih mengutamakan temuan observasi terhadap berbagai fenomena yang ada, wawancara yang dilakukan oleh peneliti sebagai key instrument (instrument penelitian) terhadap latar penelitian secara alami dan langsung. Teknik pengumpulan data yang digunakan dalam penelitian ini adalah observasi, dokumentasi, dan wawancara.

Sebagai analisis data peneliti menggunakan teori Miles dan Huberman (1984), yaitu data reduction yaitu perolehan keseluruhan data dari lapangan yang jumlahnya cukup banyak dan dipilih yang penting, data display yaitu pengategorian data lapangan dengan bentuk berupa teks naratif, atau berupa grafik, matrik, network (jaringan kerja), dan chart, langkah terakhir adalah conclusion drawing/verification yaitu penarikan kesimpulan dan verifikasi. ${ }^{10}$ Sebagai uji kredibel menggunakan triangulasi atau pengecekan data dari berbagai sumber dengan berbagai cara dan waktu. Peneliti sangat memanfaatkan waktu untuk menggali data, baik dengan observasi, wawancara, dokumentasi, dan lain sebagainya untuk memperoleh data, di mulai tanggal 4 Sepetember 2017 di Bulak Setro Surabaya.

9 Ahmad Amin. Etika (Ilmu Akhlak), Jakarta: Bulan Bintang. 1995, Cet. 8, 63-65

10 Sugiyono. Metode Penelitian Kuantitatif, Kualitatif, dan $R$ \& D. Bandung: Alfabeta, Cet-11, 2010, h. 246 


\section{Hasil dan Pembahasan}

\section{Sejarah dan Tujuan Pengajian}

Bulak setro merupakan sebuah perkampungan di daerah Surabaya Utara, kampung ini termasuk dalam kelurahan Bulak yang memiliki satu Rukun Warga (RW) dan 7 Rukun Tetangga (RT). Namun, dalam penelitian ini hanya 2 RT saja sebagai subjek penelitian, yaitu RT 01 yang dipimpin oleh Bapak Sumali Dermawan dan RT 02 yang dipimpin oleh Bapak Sutadji, disamping lingkungan yang bersebelahan, para remaja yang berbaur menjadi satu juga sebagai alasan dari pengambilan peneliti. Warga disini masih kental dengan kegiatan keagamaan baik berupa pengajian, slametan, ataupun lainnya.

Berdasarkan hasil wawancara peneliti dengan ketua dan tokoh masyarakat setempat bahwa pengajian remaja Bulak Setro didirikan sejak bulan Ramadhan tahun 1999, bermula dari sebuah organisasi kecil yang diberi nama IRBUS (Ikatan Remaja Bulak Setro) yang berdiri pada tahun 1998.

Seiring waktu dan kemauan para remaja serta dukungan masyarakat setempat, akhirnya pengajian ini sebagai aktifitas rutin mingguan, bulanan, bahkan tahunan bagi para remaja di sini. Selain itu, mereka menganggap bahwa dengan adanya pengajian dapat menjalin silaturrahim dengan sesama remaja sekitar, dan saling bertukar pendapat atau gagasan tentang apa yang belum mereka ketahui, terlebih dalam pengetahuan agama.

Dahulu pengajian ini hanya dihadiri segelintir orang saja, tak lebih dari 10 remaja. Namun, dengan berjalannya waktu setiap tahun semakin bertambah, hingga saat ini terdapat 50 remaja. Bagi mereka pengajian merupakan sebuah wadah untuk menambah ilmu terutama ilmu agama, dan sebagai wadah untuk mengadakan beberapa kegiatan positif lainnya.

Tujuan dari pengajian ini adalah untuk mengupayakan tercapainya cita-cita generasi muda ke arah perbaikan di bidang pendidikan dan kesejahteraan, serta terbinanya kehidupan beragama di kalangan mereka. Selain itu juga untuk mempererat ukhuwah islamiyah antara para generasi muda, mendidik mereka agar menjadi manusia yang berakhlak mulia, 
bertaqwa, menghayati dan mengajarkan ajaran Islam, serta terhindar dari lingkungan yang negatif, sehingga pada akhirnya mereka memiliki kepribadian yang bertanggungjawab terhadap pendidikan, bangsa, keluarga, dan masyarakat.

\section{Kondisi Guru/Ustadz dan Anggota}

Saat ini kepengurusan di bawah pimpinan saudara Aminun, Ustadz Samsul Ma'arif sebagai pembina pengajian remaja ini, dan Ustadz M. Sholihin Qodir sebagai tokoh masyarakat setempat. Untuk keanggotaan pengajian ini sekarang berjumlah 50 orang dengan beragam usia remaja, mulai umur 13 sampai dengan umur 23.

Sementara untuk pengajian rutinan tiap minggu, barokah kirim do'a dan Al-Fatihah dipimpin langsung oleh tokoh masyarakat setempat, dan penyampaian materi akhlak, diisi secara bergantian oleh Ustadz Samsul Ma'arif dan Ustadz Sholihin Qodir. Untuk pengajian setiap bulan diisi oleh beberapa ustadz dari luar, namun jika berhalangan, diisi dengan kegiatan banjari atau azhari yang dipimpin oleh ketua kepengurusan yaitu saudara Aminun.

\section{Latar Belakang Berdirinya Pengajian Remaja Bulak Setro}

Latar berdirinya pengajian remaja ini adalah kekhawatiran para tokoh masyarakat terhadap akhlak generasi muda (remaja), yang pada saat itu kurang mendapat perhatian dari orang tua dan lingkungan sekitar, kurangnya rasa tanggungjawab dalam memperhatikan tugas mereka sebagai seorang muslim. Kondisi zaman yang terus berkembang sehingga dapat menjerumuskan mereka dalam pergaulan yang kurang benar, dan nantinya menyebabkan keterbelakangan moral serta keterpurukan akhlak. Ustadz Sholihin mengatakan:

Menurut yang saya ketahui bahwa dulunya para remaja disini sangat enggan untuk diajak pengajian, kebiasaan mereka dalam permainan adu burung dara sangat sulit sekali dihilangkan, hingga akhirnya ada tiga sesepuh sebelum saya yang berhasil merangkul dan mengajak beberapa dari mereka yang diantaranya adalah kepala kelompoknya. Menurut yang saya ketahui awalnya ada teman mereka yang meninggal dalam usia 
muda dan tidak sakit, kemudian mereka mulai bertanya-tanya tentang kematian dan seputar agama kepada sesepuh masyarakat pada saat itu, yang kebetulan sesepuhnya adalah kakak saya sendiri. Sebagai sesepuh tentu kakak saya menjawab pertanyaan dengan bahasa yang bisa diterima oleh mereka, dan dari sinilah kakak saya sedikit demi sedikit mencoba untuk mengajak mereka untuk ikut pengajian agar mereka bisa mendapatkan pengetahuan yang lebih luas tentang agama, walaupun pada akhirnya tidak semua dari mereka yang ikut.11

Karenanya, pengajian remaja Bulak Setro sebagai bentuk wadah bagi mereka untuk benteng diri, bimbingan, dan arahan agar lebih berakhlak dan siap menghadapi segala tantangan yang akan terjadi di era seperti sekarang ini.

\section{Materi Ajar dan Metode yang digunakan}

Pelajaran yang diajarkan di pengajian remaja Bulak Setro ini sebagai berikut. Pertama, materi akhlak, sebagai bentuk pembelajaran remaja tentang pertumbuhan dan perkembangan dalam beradab, dan bergaul terutama cara bertingkah, bertutur kata, berbusana, sopan santun dan menghormati orang lain yang baik menurut pendidikan agama. Dengan demikian diharapkan terdapat perubahan sikap dari remaja menuju kedewasaan dalam pola pikir dan bertingkah laku. Kedua, materi ibadah yang meliputi tata cara beribadah menurut ajaran Islam sehingga mereka dapat menerapkan di masyarakat. Ketiga, materi tentang cara berorganisasi secara islami di lingkungan mereka.

Untuk metode yang digunakan dalam pengajian ini ialah metode ceramah, tanya jawab, dan diskusi. Sementara dalam penyampaian materi, khususnya materi akhlak, terdapat beberapa proses dan cara yang dapat dilakukan dalam pembentukan akhlak generasi muda, antara lain melalui: pembiasaan, pergaulan, keteladanan, dan pemberian beberapa latihan.

\section{Faktor Pendukung dan Penghambat}

1 Hasil wawancara dengan Ustadz Sholihin Qodir Tanggal 15 September 2017, 
Faktor pendukung pelaksanaan pengajian diantaranya dorongan para orang tua agar anaknya ikut dalam pengajian ini, guru atau ustadz yang profesional dan berkompeten dalam bidangnya serta memahami apa yang dibutuhkan para remaja, partisipasi para remaja senior yang selalu mengajak teman sebayanya untuk mengikuti pengajian ini. Sedangkan faktor penghambatnya adalah keadaan lingkungan, ekonomi remaja yang terbatas, dan kurang sadarnya dalam waktu.

\section{Sarana Prasarana dan Kegiatan-Kegiatan}

Pengajian ini dilaksanakan di Musholla Abdul Qodir yang berada di lingkungan Bulak Setro, dengan sarana dan prasarana yang sederhana, seperti: recorder, meja lipat, piring, gelas, dan karpet gulung. Adapun kegiatan yang dilaksanakan adalah kegiatan rutin mingguan setiap Kamis malam Jum'at, kegiatan bulanan setiap Jum'at Kliwon, kegiatan keagamaan setiap hari besar Islam, seperti pembacaan diba' pada bulan maulid, dzikir dan istighosah pada Isro' Mi'roj dan lain sebagainya. Kegiatan bakti sosial seperti santunan anak yatim pada bulan Muharrom, bagi-bagi ta'jil pada bulan ramadhan, dan lainnya. Kegiatan tahunan yaitu ziarah wali 5 yang biasanya diadakan pada akhir tahun.

Untuk acara pengajian yang berlangsung pada Kamis malam Jum'at, saudara Aminun sebagai ketua pengajian menjelaskan sebagai berikut :12

Pengajian Kamis malam Jum'at berlangsung dari pukul 19.00 - 20.30 WIB para jamaah mulai membuka kitab Al-Qur'an atau kitab Ta'limul Muta'allim. Adapun agenda pengajiannya yaitu:

a. Pembacaan Diba'iyah singkat (Sholawat Nabi Muhammad SAW)

b. Pembacaan barokah Al Fatihah

c. Pembacaan Tahlil dan Istighosah, atau pembacaan salah satu surat pilihan: Surat Yasin, Surat Al Waqiah, dan Surat Al Mulk

d. Sorogan kitab Ta'limul Muta'allim

e. Do'a (Penutup)

\section{Kontribusi Pembentukan Akhlak}

12 Hasil Wawancara dengan ketua pengajian saudara Aminun pada tanggal 17 September 2017, Jam 19.50 
Kontribusi pengajian remaja dalam pembentukan akhlak adalah semenjak diadakan pengajian ini, musholla yang dulu saat sholat jamaah hanya diisi para orang tua saja, kini diisi para remaja. Namun, yang lebih tampak kontribusinya adalah rasa saling mengingatkan dalam diri mereka sehingga mengajak para remaja lainnya untuk mengaji, dan sebagai bentuk latihan untuk menjadi pribadi yang bertanggungjawab, di antara mereka menjadi tutor temannya dalam mengaji Al-Qur'an. Sedangkan untuk acara bulanan mereka juga tidak segan untuk meminta pendapat dari tokoh masyarakat setempat.

Beberapa masyarakat juga mengatakan bahwa para remaja di sini lebih memiliki unggah-ungguh terhadap orang yang lebih tua, walaupun tidak semua. Salah seorang masyarakat yang bernama Pak Fauzi mengatakan:

Para remaja disini sangat dikenal dengan jalinan persaudaraan yang sangat kuat, memang saya akui kebiasaan jelek yang lama masih ada, tapi biarpun demikian berbeda dengan dulu, jika dulu mereka tak tergerak hatinya sama sekali untuk ikut dalam pengajian, sekarang mereka sudah tergerak, sehingga bisa dikatakan biarpun berdosa tapi tetap berusaha untuk mensucikannya. ${ }^{13}$

Hal di atas dapat dibuktikan dengan hasil angket yang tersebar bahwa 90\% menyatakan bahwa mereka mengakui pengajian menjadikan diri mereka lebih baik.

\section{Simpulan}

Berdasarkan uraian di atas dapat disimpulkan bahwa pengajian remaja sebuah wadah bagi mereka untuk menjalin ukhuwah Islamiyah dan belajar agama, sebagai bekal untuk masa depan mereka sehingga mampu membentuk kepribadian yang sholeh ataupun sholehah.

Bulak Setro ini sebagai gambaran bahwa pengajian remaja memiliki kontribusi yang sangat besar dalam pembentukan akhlak generasi muda di kemudian hari, wilayah ini mempersiapkan generasinya dengan hal positif sehingga menjadi sebuah kebiasaan bagi para remaja menghadiri sebuah

${ }^{13}$ Hasil wawancara dengan salah seseorang masyarakat yang bernama Pak Fauzi pada tanggal 27 September 2017, Jam 18.30 
pengajian, sebagai latihan penanaman rasa tanggungjawab dengan menjadi tutor, tanpa menghilangkan masa remaja mereka, karena masyarakat tetap memberi kebebasan bagi mereka untuk bermain dan bergaul seperti layaknya remaja lainnya.

\section{DAFTAR PUSTAKA}

Ahira, Anne. 2012. Terminologi Kosa Kata. Jakarta: Aksara.

Ali, Mohammad Daud. 2008. Pendidikan Agama Islam. Jakarta: Rajawali Press.

Amin, Ahmad. 1995. Etika (Ilmu Akhlak). Jakarta: Bulan Bintang.

Cahyaningsih, Dwi Sulistyo. 2011. Pertumbuhan Perkembangan Anak dan Remaja. Jakarta: Trans Info Media.

Chirzin, Habib. 1983. Pesantren dan Pembaharuan. Jakarta: LP3ES.

Depag RI. 1983/1984. Al Qur'an dan Terjemahannya. Jakarta: Proyek Pengadaan Kitab Suci Al-Qur'an 1983/1984.

Dewan Redaksi Ensiklopedia Islam. 1997. Ensiklopedia Islam. Jakarta: Ichtiar Baru Van Hoeve.

Dirdjosanjoto, Pradjarta. 1999. Memelihara Umat (Kiai Pesantren-Kiai Langgar di Jawa). Yogyakarta: LKIS.

Djoenaesih, Soerjono. 1997. Istilah Komunikasi. Yogyakarta: Liberty.

Djony, Gunadi. 2013. Istilah Komunikasi. Jakarta: Grafindo Persada.

Dradjat, Zakiah. 1970. Ilmu Gama. Jakarta: Bulan Bintang.

Drajat, Zakiah. 1995. Remaja Harapan dan Tantangan. Jakarta: Ruhama.

Ghazali, Bahri. 2003. Pesantren Berwawasan Lingkungan. Jakarta: Prasasti. 
Hasbullah. 1999. Kapita Selekta Pendidikan Islam di Indonesia. Jakarta: Raja Grfindo Persada.

King, Laura. 2012. The Science Of Psicology: An Appreciative View. Jakarta: Salemba Humanika.

Mustafa. 2005. Akhlak Tasawuf. Bandung: Pustaka Setia.

Nata, Abuddin. 2009. Akhlak Tasawuf. Jakarta: Rajawali Pers.

Nurwahid, Hidayat. 2012. Pengantar Sejarah Dakwah. Jakarta: Kencana.

Ramayulis. 1994. Ilmu Pendidikan Islam. Jakarta: Kalam Mulia.

Saebani, Beni Ahmad, Abdul Hamid. 2012. Ilmu Akhlak. Bandung: Pustaka Setia.

Salim, Abdullah. 1986. Akhlak Islam Membina Rumah Tangga dan Masyarakat. Jakarta: Seri Remaja.

Sugiyono. 2010. Metode Penelitian Kuantitatif, Kualitatif, dan R \& D. Bandung: Alfabeta.

Suparta, Munzier. 2009. Metode Dakwah. Jakarta: Kencana.

Suraji, Imam. 2006. Etika Dalam Perspektif Al- Qur'an Dan Hadits. Jakarta: Pustaka Al-Husna Baru.

Suryabrata, Sumadi. 2008. Psikologi Pendidikan. Jakarta: Rajagrafindo Persada.

Tim Redaksi Kamus Besar Bahasa Indonesia. 2005. Kamus Besar Bahasa Indonesia Edisi Ketiga. Jakarta: Balai Pustaka.

Yusuf, Syamsul. 2010. Psikologi Perkembangan Anak dan Remaja. Bandung: Remaja Rosdakarya.

Zulkifli. 2002. Psikologi Perkembangan. Bandung: Remaja Rosdakarya. 